\title{
Urban planning and archeological conscience: The impact of soil sealing on archaeological sites
}

\author{
Planificación urbana y conciencia arqueológica: Impacto del sellado del suelo en yacimientos \\ arqueológicos \\ Planeamento urbano e consciência arqueológica: Impacto da impermeabilização do solo em \\ sitios arqueológicos
}

\section{García Rodríguez \\ M.P. ${ }^{\circledR, 1}$}

mpgarcia@ucm.es

\begin{tabular}{l} 
Álvarez García B. ${ }^{2}$ \\
\hline @ Corresponding Author \\
\\
${ }^{1}$ Dpto. Análisis \\
Geográfico Regional \\
y Geografía Física. \\
Facultad de Geografía \\
e Historia. Universidad \\
Complutense de Madrid. \\
C/Prof. Aranguren, s/n. \\
28040 Madrid, Spain. \\
${ }^{2}$ Dpto. Historia Moderna. \\
Facultad de Geografía \\
e Historia. Universidad \\
Complutense de Madrid. \\
C/Prof. Aranguren, s/n. \\
28040 Madrid, Spain.
\end{tabular}

Received: 26.10.2016 | Revised: 17.02.2017 | Accepted: 08.03.2017

\section{ABSTRACT}

Soil sealing (permanent covering of an area by impermeable artificial material) is one of the most serious problems affecting ecosystems in Western Europe. Numerous studies have analysed this issue from an ecological approach, but very few take into account its impact on one of soil's essential functions, namely the preservation of archaeological sites. Spanish laws on historic heritage (1985) and environmental impact (2013) have tackled the matter by legislating measures for the preservation of heritage. Furthermore, in 1992 Spain signed the Valletta Treaty (the European Convention on the Protection of the Archaeological Heritage) of the Council of Europe, and further ratified it in 2011. Historians, archaeologists and soil scientists should respond to this threat using a multidisciplinary approach. The present study analyses the impact that soil sealing has had on the Roman city of Complutum, located on the Henares River plain (Madrid, España) on highly fertile Fluvisols and Calcisols. One of the aims of this study is to show that the combined use of aerial photos and satellite images provides a continuously updated file of urban development processes and therefore makes it possible to foresee the impact on archaeological sites. At present, medium and high spatial resolution images (Spot and Landsat satellites) can be obtained free of charge and digital processing makes it possible to map any variations in these sites. Another aim of the study is to analyse the importance of soil type and quality in establishing settlements in corridors which have served as important communication routes. There is a greater likelihood of urban planning and development processes in the immediate surroundings of these routes over the years, implying that it is highly probable that pre-existing sites will be destroyed.

\section{RESUMEN}

El sellado de suelos es uno de los problemas más graves que afecta a los ecosistemas de Europa occidental. Numerosos estudios lo han analizado desde un enfoque ecológico pero pocos tienen en cuenta su influencia en una de las funciones primordiales del suelo: la preservación de restos arqueológicos. Las leyes españolas de Patrimonio Histórico (B. O.E. 1985) y de Impacto Ambiental (B.O.E. 2013) abordan el problema legislando medidas para la preservación del patrimonio. España firmó también, en 1992, el Tratado de Malta (Convención Europea de Protección de la Herencia Arqueológica) del Concilio de Europa. En 2011 ratificó este tratado. Historiadores, arqueólogos y edafólogos deben afrontar este reto desde un punto de vista pluridisciplinar. En el presente estudio se analiza el impacto que el sellado del suelo ha tenido en la ciudad romana de Complutum, situada en la vega del rio Henares (Madrid, España) sobre Fluvisoles y Calcisoles muy fértiles. Uno de los objetivos del estudio es mostrar cómo la combinación de fotografías 
aéreas e imágenes de satélite proporciona un archivo continuamente actualizado de los procesos de desarrollo urbano, lo que permite prever el impacto sobre los yacimientos arqueológicos. En la actualidad, las imágenes de satélites de resolución media y alta (Landsat y Spot) se pueden obtener de forma gratuita y la posibilidad de distintas mejoras digitales permite cartografiar los cambios en los yacimientos. Otro objetivo del estudio es analizar la importancia que tienen los tipos y la calidad de los suelos en el establecimiento de las poblaciones en un corredor que siempre ba sido una importante ruta de comunicación. Existe una mayor probabilidad de que los procesos de planificación y desarrollo urbanos hayan sucedido, a lo largo de los años, en el entorno inmediato de esta ruta, lo que implica un mayor riesgo para los yacimientos preexistentes.

\section{RESUMO}

A impermeabilização do solo é um dos mais sérios problemas que afetam os ecossistemas na Europa Ocidental. Esta problemática tem sido analisada, do ponto de vista ecológico, por numerosos estudos, mas muito poucos têm em conta o seu impacto ao nível de uma das muitas funçôes do solo: a preservação dos sítios arqueológicos. As leis espanholas referentes ao Património Histórico (1985) e de Impacto Ambiental (2013) abordam o problema legislando medidas para a preservação do património. Além disso, Espanha assinou também em 1992 o Tratado de Valletta, também conhecido como Convenção de Malta (Convenção Europeia de Proteção do Património Arqueológico) do Conselho da Europa, posteriormente ratificado em 2011. Historiadores, arqueólogos e pedólogos devem responder a este desafio usando uma abordagem multidisciplinar. O presente estudo analisa o impacto que a impermeabilização do solo teve na cidade Romana de Complutum localizada na veiga do rio Henares (Madrid, Espanha) sobre solos muito férteis classificados como Fluvissolos e Calcissolos. Um dos objetivos deste estudo é mostrar que o uso combinado de fotografias aéreas e imagens de satélite proporciona um arquivo continuamente atualizado dos processos de desenvolvimento urbano permitindo prever o seu impacto nos sitios arqueológicos. Atualmente, as imagens de satélite (Spot e Landsat) de resolução média e alta podem ser obtidas de forma gratuita e o seu processamento digital permite cartografar as alteraçôes que ocorrem nesses sítios. Outro objetivo deste estudo é o de analisar a importância do tipo e qualidade do solo no estabelecimento das populaçôes em corredores que têm servido como importantes vias de comunicação. Existe uma maior probabilidade de que o planeamento urbano e os processos de desenvolvimento tenham ocorrido, ao longo dos anos, nas zonas envolventes destas vias, o que implica que é altamente provável que os sítios arqueológicos pré-existentes tenham sido destruidos.

\section{Introduction}

Soil sealing is the permanent covering of an area of land and its soil by impermeable artificial material, such as asphalt and concrete (European Comission 2012). It was identified as one of the main soil degradation processes in the Soil Thematic Strategy (COM 2006) of the European Commission and in the latest report of the European Environment Agency on the status of the European environment (European Comission 2012). Its extent and increase is significant. Soil sealing is one of the most serious problems affecting ecosystems, and particularly in Europe, with an estimated 9\% loss of soil in recent years (Scalenghe and Ajmone-Marsan 2009).

The proposed Soil Framework Directive, COM (2006), considers the following environmental, economic, social, scientific and cultural functions of soil:

(a) food and other biomass production, including in agriculture and forestry;

(b) storing, filtering and transforming nutrients, substances and water, as well as replenishing bodies of groundwater; 
(c) basis for life and biodiversity, such as habitats, species and genes;

(d) physical and cultural environment for humans and human activities;

(e) source of raw materials;

(f) acting as carbon reservoir;

(g) archive of geological, geomorphological and archaeological heritage.

Many researchers have worked on studies of the effects of soil sealing in the first six research areas (Lavalle et al. 2001; Zhang et al. 2003; Blum et al. 2004; Van Camp et al. 2004; EEA 2006; Montanarella 2007; Tomás et al. 2010; Jones et al. 2004; García-Alvarado et al. 2014), but few of them have researched the last area, archive of archaeological heritage, in any depth, although one of the most important functions of the soil is the preservation of archaeological sites, essential for the study of the history of the earth and of mankind (Blum 2005).

Current land use studies in Spain take into account the protection of archaeological sites by observing the legislation regarding urbanization (Law on historic heritage, 1985, and Law of environmental impact, 2013), but even despite this, sealing is still causing the disappearance of many remains. In 1992 Spain signed the Valletta Treaty (the European Convention on the Protection of the Archaeological Heritage). It was further ratified in 2011. This is a multilateral treaty of the Council of Europe to protect the European archaeological heritage as a source of European collective memory and as an instrument for historical and scientific study. Among its main objectives it is to integrate the conservation and archaeological investigation of archaeological heritage in urban and regional planning policies (Council of Europe 1992, http:// www.coe.int/).

At present in Spain, in compliance with European legislation, archaeological surveys are carried out before starting any infrastructure. However, until the 1980s these surveys were not mandatory and the widespread urban development during the years 1960-1980 led to the destruction of many archaeological sites. This occurred in many different places worldwide and numerous scientific articles have found it to be the main reason for the destruction of archaeological sites, along with theft and vandalism (Asamerew et al. 2002; Shoup 2006; Al-Houdalieh and Sauders 2009; El-Bayomi and Ali 2015).

The collaboration between historians, archaeologists and soil scientists is crucial for tackling this issue. All researchers require soil, geoarcheological and environmental studies, and it is also essential to carry out an archaeological study before planning new urban development in a municipality to prevent the destruction of heritage (UNESCO 1969). In addition, collaboration between archaeologists and urban planners may help to project the future development of cities since land use and planning in the past may offer useful information for current construction guidelines (Smith 2010). This work presents a paradigmatic case of the impact of poor urban planning on sealing and the disappearance of important archaeological sites, and with it the impossibility of accurately analysing the history of populations. For this study we selected the Roman city of Complutum in Alcalá de Henares (Madrid) (Figure 1).

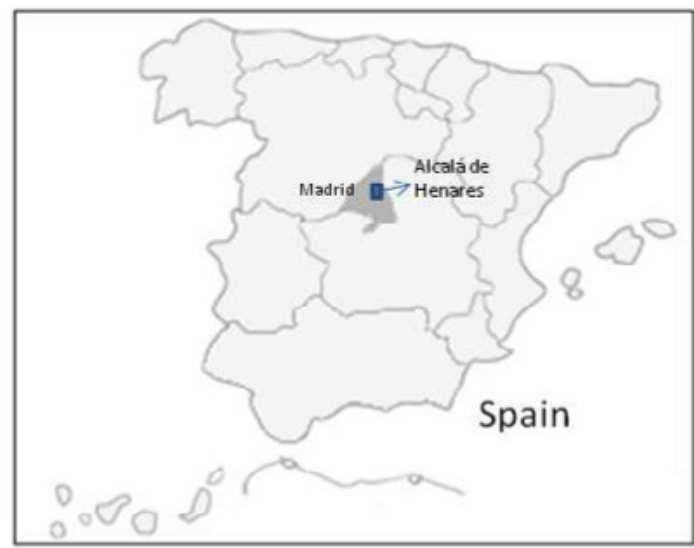

Figure 1. Study area.

The city developed between the 1st and 7th centuries on the plain of the Henares River. Previously, during the Republic, the settlement was located further to the south on the limestone uplands of the Cerro de San Juan del Viso. From the Middle Ages - after the fall of the Empire- the city moved eastwards on the same floodplain on the nearby Tertiary hills. It is important 
to examine the reasons these settlements moved over time in order to understand the history of the various civilisations and their impact on the natural environment. To a large extent these displacements were due to the varying importance given during the planning process to topography and the quality of the soil. Unfortunately, most of the settlements in this area (Figure 2), which had been conserved for centuries, were destroyed by the urban development of the city of Alcalá de Henares in the 1970s and 1980s. This particularly affects the remains of Complutum, where it has been calculated that 25 of the 50 hectares comprising the site have disappeared below residential buildings and industrial warehouses in the neighbourhood of El Juncal and the surrounding area in the Los Reyes district (Sánchez Montes and Rascón Marqués 2011). Fernandez-Galiano and Garcés-Toledano (1978) have used UTM coordinates to identify the exact location of archaeological sites in the valley of the Henares River. Although some of these archaeological remains, including mosaics, were extracted and are now conserved in the Archaeological Museum in Alcalá de Henares, many more have disappeared under new buildings. The work of these authors offers an overview of the magnitude and importance of the loss of archaeological remains in this region.

Remote sensing and GIS have for some time been used to map soil sealing (Netzband and Meinel 1998; Zhang et al. 2003; Raymaekers et al. 2005; Moeller 2005; Kampouraki et al. 2006; García et al. 2014); Though many authors research on remote sensing and archaeology (Custer et al. 1986; Altaweel 2005; Wiseman and El Baz 2007; Crutchley 2009; Parcak 2009; Giardino 2011; Lasaponara and Masini 2011, 2012), however, these techniques have only rarely been applied in research relating to the disappearance of archaeological sites. In a study of archaeological sites on the flood plain of the Nile River, Parcak (2007) uses satellite imagery to show that applying multispectral analysis with high spatial resolution satellite images is very useful to quantify the destruction of archaeological remains in Egypt and also in other sites in Israel, Turkey, Syria, Jordan, etc. ElBayomi and Ali (2015) use remote sensing and GIS to analyse expansive urban development in El Minya Archaelological Sites. This article is intended as a first approach to this type of study.

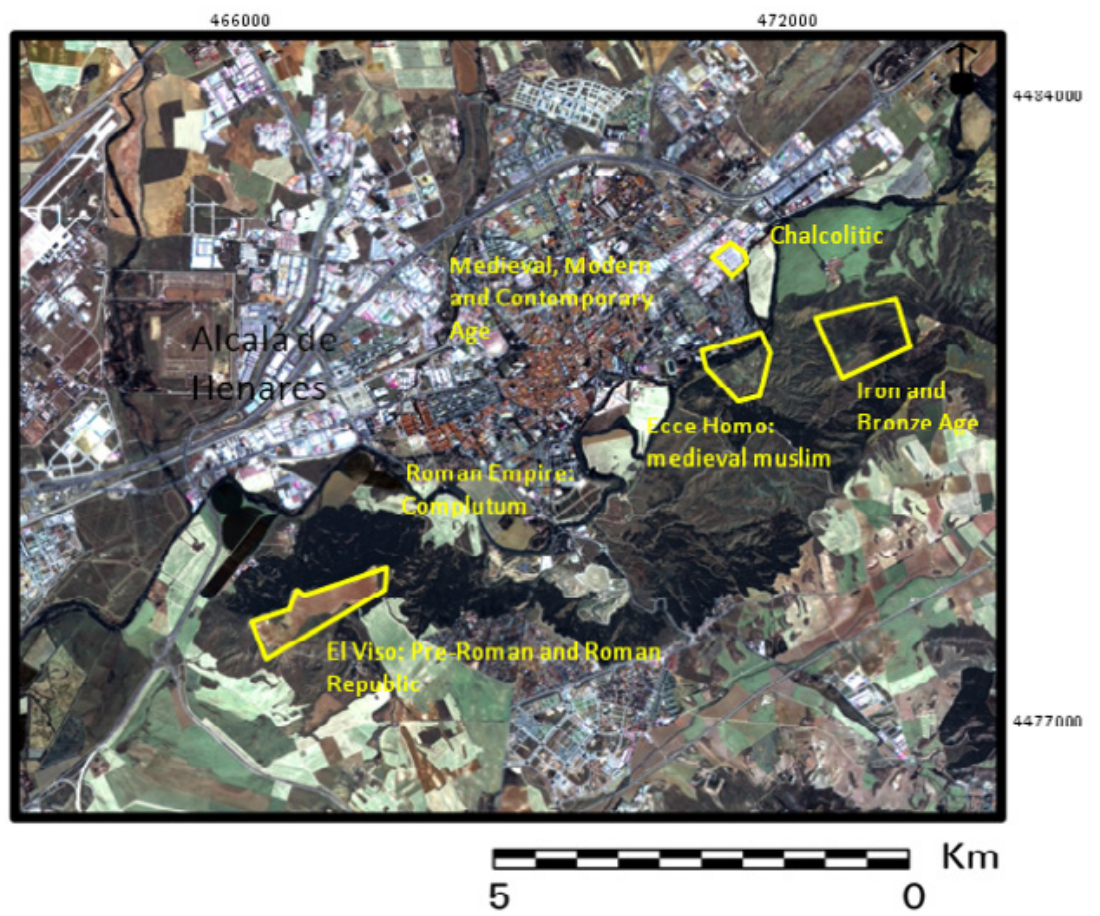

Figure 2. Alcalá de Henares: archaeological deposits. Multispectral Landsat-8 image (7-4-2, R-G-B), 2013/06/16. 


\section{Materials and methods}

In this paper we propose a methodology to track and evaluate soil sealing and its implication in the destruction of archaeological remains using aerial photographs and satellite images, which are widely available in any country and provide ongoing updates of the spatial information that is not dependent on local authorities. These techniques for monitoring territorial and landscape changes should be included in land management studies and planning. Also included in this study is a GIS-based analysis of the relationship between settlements and soil quality and type.

To track the evolution of sealing we used aerial photography from the historic series available from the Madrid Regional Government (www. madrid.org), satellite images from the Spanish Teledetection Plan (IGN), in the Global Land Survey Facility programme (Maryland University), and Google Earth ${ }^{\circ}$. We selected photographs from the years 1956 and 1975 -before and after the urban construction boom in the city- an image from the TM sensor of the Landsat-5 satellite (25-389) and recent images from the Spot-5 (8-7-2013) and Landsat-8 satellite (11-8-2013). The images and photographs were processed with the ERDAS Imagine-11 program, georeferenced to geographic coordinates, and subjected to different spectral and spatial enhancements. Other resources used were soil association maps, maps for agricultural potential drawn up by Monturiol and Alcalá (1990a, 1990b), and population data from the INE (www.ine.es). The soil map has been adapted to the FAO classification (IUSS Working Group 2007) and the agricultural potential map to the Klingebiel and Montgomery classification (1961).
3. Settlements' development of Alcala de Henares in regard of soils' types

The municipal district of Alcalá de Henares and the surrounding area contain sites with numerous archaeological deposits. Unfortunately, a large part of them have now disappeared due to soil sealing.

The presence of the different settlements responds to a series of natural factors. The relief of the area is shaped by the Henares River, and constitutes an asymmetric valley with a fertile river plain at an altitude of $580-590 \mathrm{~m}$. On the right bank there are various terraces and on the left is the Miocene upland area with an altitude of $800-880 \mathrm{~m}$, and steep vertical cliffs (Acaso et al. 2007). This area has been broken up due to erosion by torrents, giving rise to badlands with alluvial fans, glacis and triangular facets, and some isolated hills (Ecce Homo, Viso de San Juan, etc.). The early populations settled on these uplands, as they had a markedly defensive character. El Viso de San Juan, to the southwest of today's city of Alcalá de Henares, with very poor soils and a high degree of erosion (Cambisols and Regosols), was settled by Celtiberians and Romans who gave priority to defence rather than the fertility of the valley. The first Roman city- of which scarcely anything is known- was raised on the original Celtiberian citadel located on the crest of the hill. The original urban layout probably followed the customary Roman model in around the first century B.C., perhaps at the time of Caesar.

The Ecce Homo hill to the southeast of the city, with soils (Cambisols and Regosols, IUSS Working Group 2007) under high risk of erosion, is a site of Bronze and Iron Age remains. Here and in the surrounding area was the site of the Q'alat abd Al-Salam mediaeval Muslim city. Once again in this case the main priority was the defensive function due to the nearby Christian frontier, so the settlement evolved in a cluster around the fortress. After the Christian Reconquest, the city was re-established on the Henares River plain, in closer proximity to more 
fertile lands. This new nucleus was known by the name of Burgo de Sant luste, and was the origin of what is today Alcalá de Henares.

The floodplain and the first terrace of the Henares River also preserve -in addition to Complutumsome remains from the Chalcolithic period in the Esguevarita, along with the Roman town of El Val. These settlements benefited from fertile soils (Fluvisols and Regosols, IUSS Working Group 2007) and easy access to water resources, which enabled agriculture and grazing. A large part of these archaeological sites have vanished, since in 2008 the City Council approved the urban development of the area with the consequent sealing of the soils and destruction of heritage (although many of the remains had disappeared in previous decades).

The most important site of all, however, is that of Complutum. The Roman imperial city was built on the plain and the first terrace of the Henares River, near the Camarmilla stream with Calcic and Eutric Fluvisols (land capability class II), Haplic Calcisols, Calcic Luvisols, Eutric Cambisols and Calcaric Regosols (IUSS Working Group 2007) (land capability class I) (Figures $3 a$ and $3 b$ ).

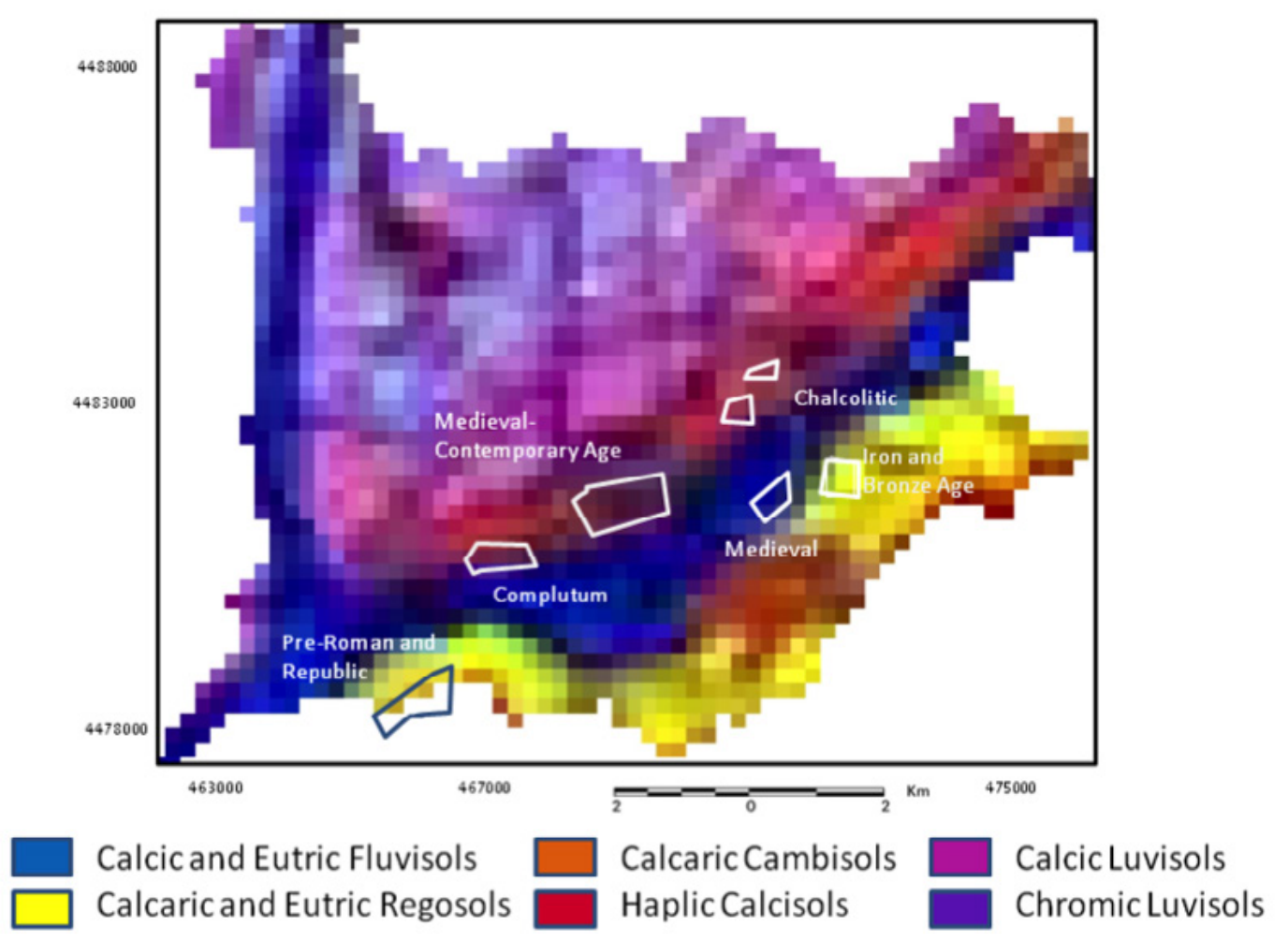

Figure 3a. Alcalá de Henares: soil association map (Monturiol and Alcalá 1990a).

Between the time of Claudius and Augustus, in the first half of the first century A.D., the Roman settlement moved from the uplands of El Viso de San Juan to the plain, and covered an area of about 50 hectares. This decision must have been costly, and there must therefore have been some fairly weighty motives for doing so. Probable factors include the improved quality and richness of the farmlands and grazing, and the access to major communications routes (from Emerita Augusta to Caesaraugusta and Tarraco and from the north to Carthago Nova), whose construction had been favoured by flat land, nearby water and the need for building space, in addition to the commercial importance of the area. Proximity to the Fuente del Juncal 


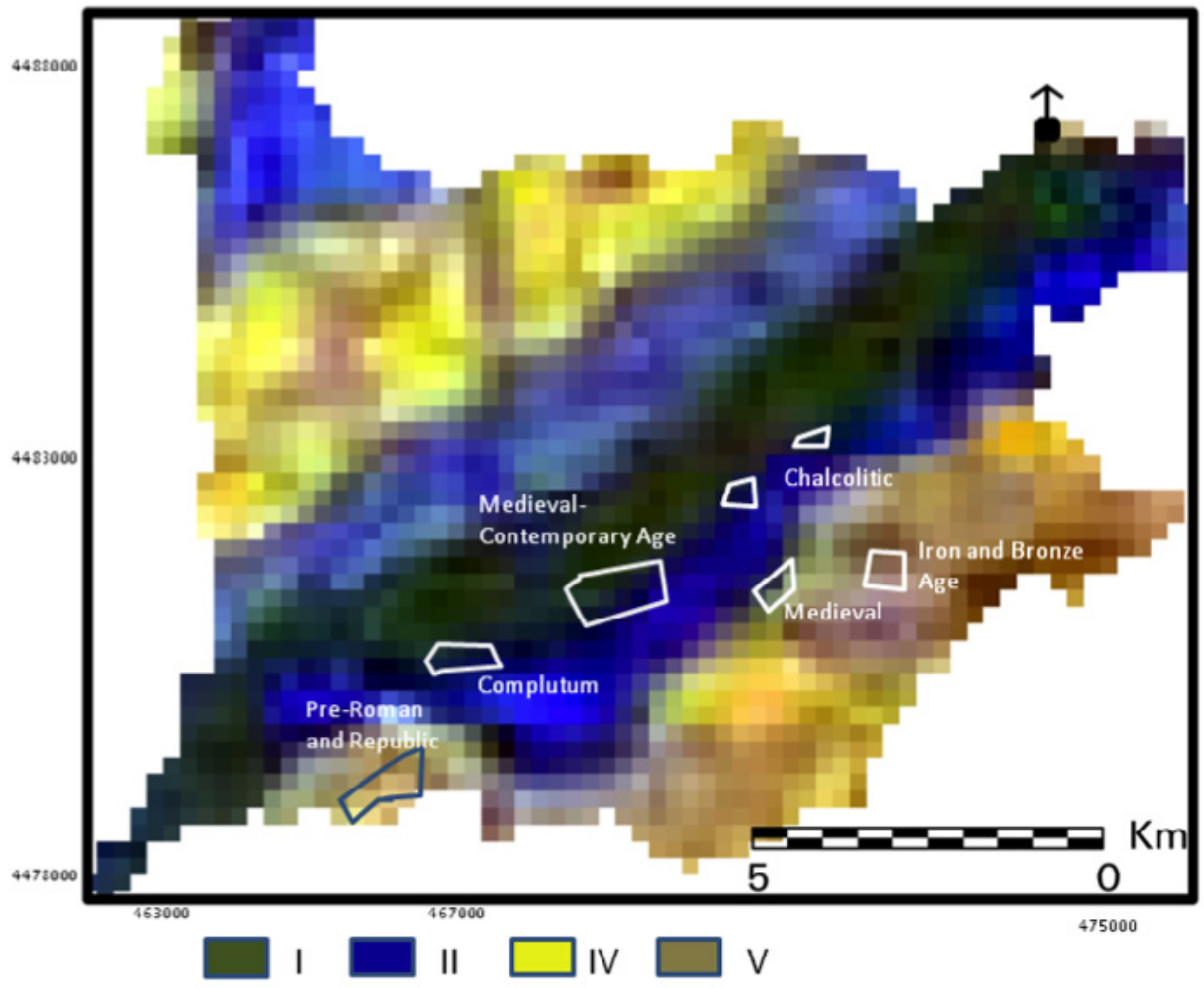

Figure 3b. Alcalá de Henares: agricultural potential map (Monturiol and Alcalá 1990b).

must also have played a key role, as since ancient times it had been a place of worship owing to its mineral-rich waters and springs (Sánchez Montes and Rascón Marqués 2011). Thus a city evolved which was a prime example of the Roman urban layout, conditioned by the presence of primary communications routes, as the road that linked Emerita Augusta and Caesaraugusta became the city's decumanus maximus. The first works for moving the city date from the era of Augustus and were concentrated in the area near the Fuente del Juncal in what was eventually the oldest and westernmost neighbourhood, known by the name of Regio I. But it was finally under Claudius, towards the year 50 A.D., when the real impetus for moving the city was seen. This was when the definitive urban layout was designed, to which some later modifications were made, particularly in the final years of the 3rd and in the early 4th century, the era of greatest prosperity for Complutum.
This remodelling however had little effect on the general structure as it mainly affected certain notably important or significant buildings.

\section{Results and discussion}

The study of the aerial photographs (Figures 4 and 5) and the satellite images (Landsat 8 , Figure 2 and Spot 5, Figure 6) reveals that until the 1970s the old Roman city had barely been affected by human activity. In 1956 we can see no constructions beyond the old mediaeval centre, Burgo de San Juste, which constitutes the origins of the city of Alcalá de Henares today. But the urban development of the town in 


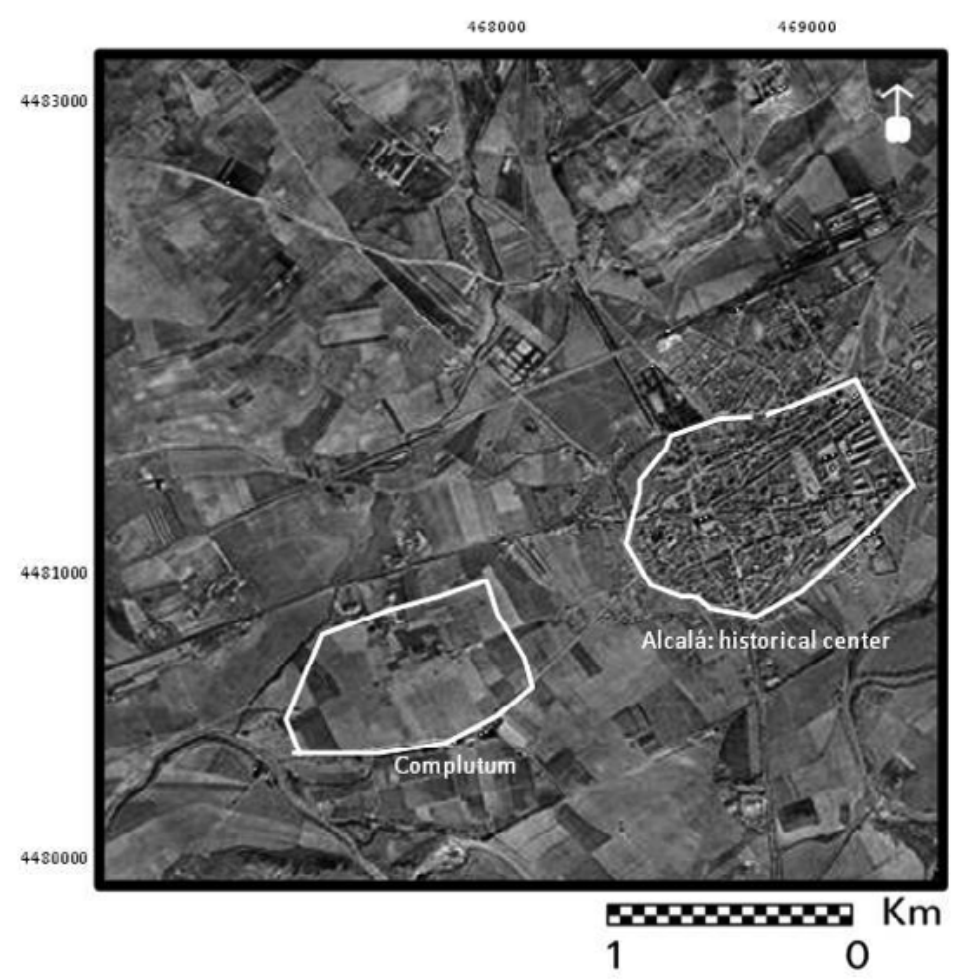

Figure 4. Aerial photographie, 1956. Until the 1970 s the old Roman city had barely been affected by human activity. In 1956 we can see no constructions beyond the old mediaeval centre.

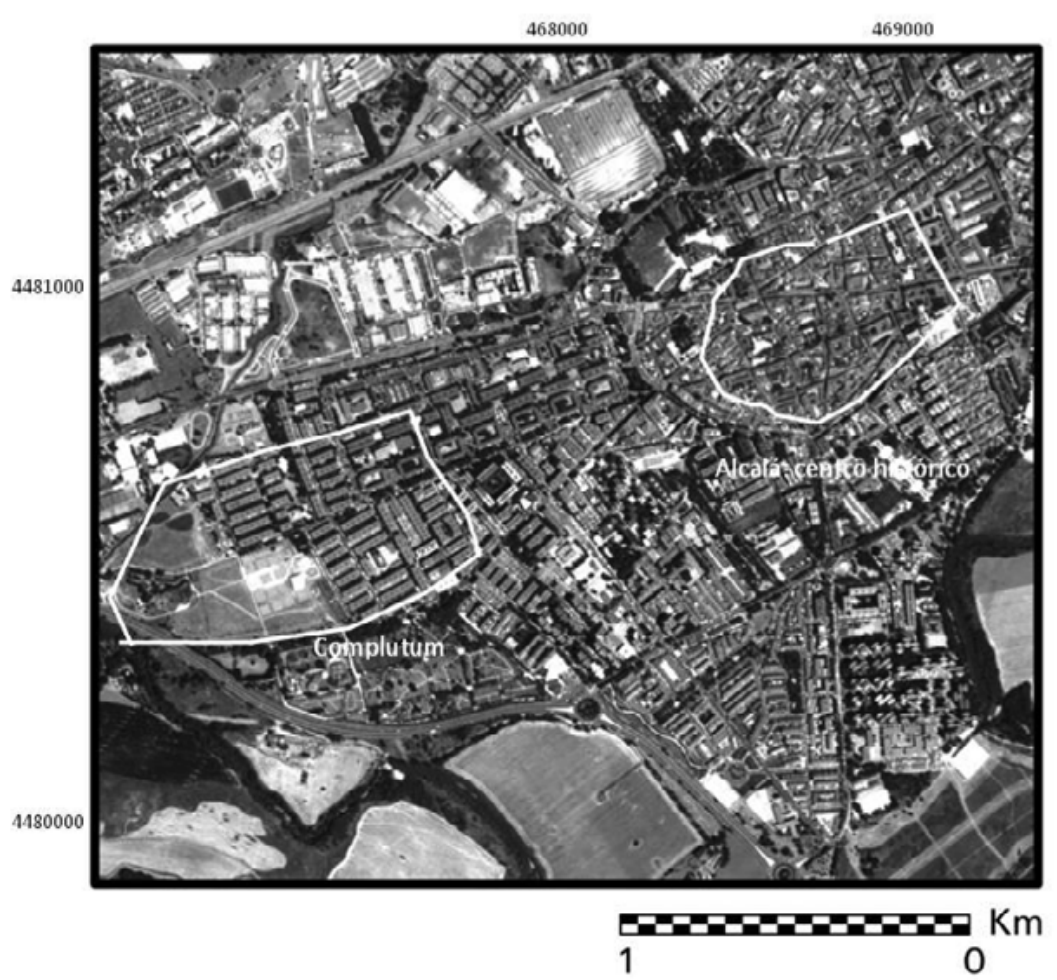

Figure 5. Aerial photographie, 1975. The urban development of the town in 1975 brought the greatest devastation of archaeological deposits 
1975 brought the greatest devastation of ruins, and in 2013 over $66 \%$ of the Roman city (35 ha) had disappeared under the sealing caused by the extension of the Alcalá de Henares city, to respond to the boom in the population in recent years. The 1970 census recorded 57,354 inhabitants, a figure which almost doubled in 1975. By 1981 it had risen to 137,169 , and today stands at around 205,000 (www.ine.es). This involved a major urban development, planned without taking account of the archaeological sites which have now been buried under the buildings and factories built as part of the development of the Henares Corridor (MadridAlcalá de Henares).

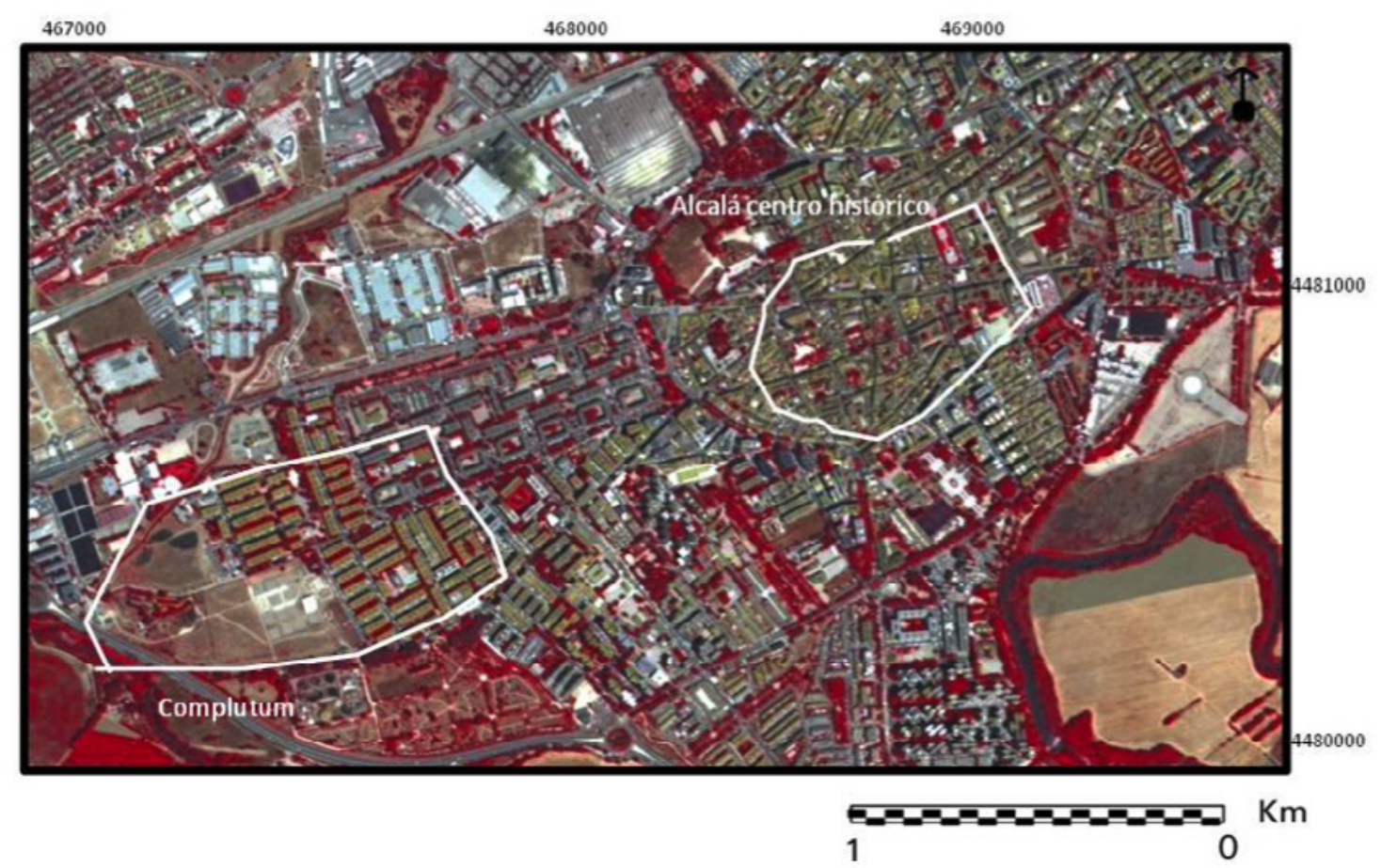

Figure 6. Spot-5 Image: combination of pancromatic and multispectral (4-3-2, R-G-B) channels (2013/07/08). Over $65 \%$ of the Roman city ( $35 \mathrm{ha}$ ) had disappeared under the sealing soil caused by the extension of Alcalá de Henares city.

Analysing the images of the satellites Landsat and Spot of 2013 , it is clear that $65 \%$ of the Roman city has disappeared below residential buildings of four storey units with basements and deep foundations. This figure has been calculated from measures made upon the images on the basis of the settlement's known surface. Upon inspection of the preserved archaeological site and analyzing the aerial photographs and the satellite images, one observes that all of the remains are to be found on the surface. As a result, the building development has destroyed a large part of the site. All that has been preserved was that taken prior to the urban development and deposited in the Archaeological Regional Museum of
Alcala de Henares (Fernández and Garcés 1978). These buildings were constructed in the urban expansion of the 1970s and early 1980s, before the laws for the Protection of Historical Patrimony came into force and therefore there was no legal framework to protect the site.

Whilst in certain cases the superimposition of buildings has resulted in the preservation of archaeological remains, as indicated in the studies published by numerous authors (Hall 1989; Cirujano and Laborde 2001; Cammas 2004; Nixon 2004; Kars and Van Heeringen 2008; Devos et al. 2013; Gregory and Matthiesen 2013; Milek and Toberts 2013), this is not the case with the Complutum site. The central 
section of the site is occupied by buildings whose deep foundations have altered the archeological remains. Industrial warehouses and sporting complexes have been built to the north and the west, and although with shallower foundations, these have also not conserved the remains. It has clearly been a destructive process of construction. Fortunately, nowadays both the laws and national and European conventions for the preservation of archaeological remains are rigorously complied with. Upon analysis of the latest images of Google Earth (publicly available) and the Sentinel satellite (launched by the European Space Agency on 23 June 2015 and available on the webpage of the National Geographic Institute) one can observe the interruption of the urbanization and subsequent soil sealing, thereby preserving the remains of the Complutum site. This is not the case however with nearby sites, with less protection and less touristic impact, where the pressure of industry and their smaller size puts them at risk.

Although there is no current development in Complutum, the presence of sealed soils surrounding the site modifies the water cycles and lowers the infiltration in a highly floodprone area, which in turn may alter the preservation of the archaeological remains. It is recommended that a study be carried out on site and by way of distinct aerial images (crewed planes, drones, and satellites) to ensure that the laws for urban protection are being complied with. The satellite images, given their availability over time and their increasing spectral and spacial resolution, allow a continuous supervision of the urban processes and consequently provide a permanent check on damage to the archaeological remains. In addition, by means of remote sensing techniques, regularly updated, it is possible to discover new archaeological remains that ought to be protected, which will obligate compliance with international laws covering sites, that are often ignored or covered up.

This study has been undertaken with the images of Landsat and Spot, given that these offer a series of images from the 1980s until the present. However, these studies could be improved with the new satellites, such as the Sentinel series with higher resolution, or with Lidar images (Laser Imaging Detection and Ranging) which allow the calculation of building heights and the assistance of georadars. Although in this study these latter satellites were not necessary, given that the remains were to be found on the surface, they would be very useful for sites that are buried.

Further, the superposition of soil cartography over the images in which the sites have been delimited (Figures $3 a$ and $3 b$ ) has allowed us to identify the types and quality of the soils of the distinct populations. The sites were chosen on the basis of topography and quality of the soils. For example, the oldest sites (Celtiiberic and Roman) are situated for the most part at higher topographic levels (Cambisols and Regosols, IUSS Working Group 2007) with little agricultural potential, whilst from the first century BC the population moved down to the plains where there was more space, better soils (agrological capacity I and II with dominance of Fluvisols, Calcisols and Regosols, IUSS Working Group 2007) and greater availability of water. Although the Arabs once again gave priority to elevated topographies due to defensive necessities, from the time of the Christian conquest the most populous cities were located in the valleys, which has resulted in the loss of the most fertile soils in all the "Henares Corridor" (García and Pérez 2007, 2014, 2016; Pérez and García 2013; García et al. 2014).

\section{Conclusions and Recommendations}

Soil sealing is a serious environmental problem that also affects one of the primary functions of the soil: the conservation of archaeological sites. Collaboration between a range of specialists in the field of sciences and humanities is a vital prerequisite in analysing this problem. The widespread inclusion of soil sciences and other earth sciences in historical studies would lead to a greater awareness of this issue and the creation of links in order to explore the relationship between the settlement of populations and the natural environment. Multitemporal studies with aerial photography and satellite images and the 
application of Geographic Information Systems offer the possibility of conducting detailed studies into soil sealing and the preservation of cultural heritage. These techniques for monitoring territorial and landscape changes should be included as well in land management and planning. Likewise, government authorities must comply with land use planning and environmental legislation when planning urban development, under the supervision of specialists.

The important processes of urban development in Alcalá de Henares during the years of heaviest industrialization caused the destruction of great parts of the Roman ruins of Complutum. This destruction affected especially those areas where the richest houses were located. This process was favoured by the absences of both an archaeological conscience and laws demanding the remains' preservation. This process has taken place in the valley, where the most fertile soils (land capability I and II) are located and where the city developed throughout the medieval and modern period up to the present. On the other hand, the remains that have been better preserved are those settlements that did not rely in any way on the quality of the soil (land capability IV and V), but that were built as a consequence of more urgent needs, such as that of defence. Consequently, our knowledge of the Roman city has turned out to be seriously reduced. Thus it has destroyed a large part of what could have been an important source of cultural and touristic resources.

The sealing of the soil has not only resulted in the destruction of numerous archaeological remains, but also a change in the hydrological cycles due to the reduction of the permeability, which may prejudice those remains that have been preserved.

The soil sealing has also caused the loss of the most fertile soils, both in the study area and in all of the "Henares Corridor" between the provinces of Guadalajara and Madrid.

The site of Complutum has been selected due to its important archaeological value and its tourist impact. As the site is at surface level it is possible to supervise the site by way of photographs and aerial images. However the study by way of remote sensing and GIS may and ought to be extrapolated to other less known sites, which are also less protected. Furthermore, any studies of its evolution and conservation can be perfected combining the traditional techniques of photointerpretation and remote sensing with the use of images from recently launched satellites and the new techniques of laser and georadars.

The development of new construction and technological methods may allow in future the recuperation of damaged areas not only in Complutum but also at other sites. These techniques are being employed in cities such as Cartagena and Merida, where there has been excavation under the foundation of the buildings. Those projects have contributed to the establishment of a link between everyday life and monumentality (Lechuga and Martínez 2009; Nodar and Mateos 2010; Palma 2010; Bendala 2012).

In recent years there has not been any urban development at the site or on the outskirts which indicates that the patrimony protection laws are being rigorously complied with, which allows us to be optimistic looking ahead to the future.

\section{Acknowledgments}

This paper was supported by the Ministry of Science and Innovation, Government of Spain, No. CSO-2012-34785. Financial support from the Spanish Ministry of Education (FPU grant $14 / 02639$ ) is gratefully acknowledged. 


\section{REFERENCES}

- Acaso E, Martín-Loeches M, Moya ME, Ruiz B, Calonge A. 2007. Geología y Geomorfología del campus. Cuadernos del campus y Medio Ambiente: 1-24. Alcalá de Henares: EcoCampus Alcalá. Universidad de Alcalá.

-Al-Houdalieh SH, Sauders R. 2009. Building Destruction: The Consequences of Rising Urbanization on Cultural Heritage in the Ramallah Province. International Journal of Cultural Property 16(1):1-23.

- Altawee M. 2005. The use of ASTER satellite imagery in archaeological contexts. Archaeological Prospection 12(3):151-166

- Asamerew D, Cain Ch, Finneran N, Harlow M, Phillips J. 2002. Combating the destruction of Ethiopia's archaeological heritage. Antiquity 76(294):955-956.

- Bendala M. 2012. Ciudad antigua: su concepción, el significado de la forma urbanística y sus consecuencias en la investigación y la política patrimonial. In: Beltrán Fortes J, Rodríguez Gutiérrez $\mathrm{O}$, editors. Hispaniae urbes. Investigaciones arqueológicas en ciudades históricas. Sevilla: Universidad de Sevilla. p. 21-41.

- Blum WEH. 2005. Functions of Soil for Society and the Environment. Reviews in Environmental Science and Biotechnology 4:75-79.

- Blum WEH, Büsing J, Montanarella L. 2004. Research needs in support of the European thematic strategy for soil protection. Trac Trends Anal Chem. 23(10-11):680685.

- B.O.E. 1985. Ley $16 / 1985$ de 25 de junio de Patrimonio Histórico Español. BOE no 155 29/06/1985. p. 2034220352.

- B.O.E. 2013. Ley $21 / 2013$ de 9 de diciembre de Evaluación Ambiental. BOE n 296, sec. I, 11/12/2013. p. 98151-98227.

- Cammas C. 2004. Les "terres noires" urbaines du Nord de la France: première typologie pédosédimentaire. In: Verslype L, Brulet R, editors. Terres Noires - Dark Earth. Actes de la table ronde internationale tenue à Louvainla-Neuve les 09 et 10 novembre 2001. Collection d'archéologie Joseph Mertens, vol XIV. Louvain-laNeuve: Université Catholique de Louvain. p. 43-55.

- Cirujano C, Laborde A. 2001. La conservación arqueológica. Arbor CLXIX 667:691-709.

- COM. 2006. Commision of the European Communities, 232. European Union Law. 231, 232. http://eur-lex. europea.eu.

- Council of Europe. 1992. Details of Treaty No. 143. European Convention on the Protection of the Archaeological Heritage (Revised). CoE 1992. Retrieved 7 July 2012. http://www.coe.int/en/web/conventions/fulllist/-/conventions/treaty/143Council of the Europe

- Crutchley S. 2009. Ancient and modern: combining different remote sensing techniques to interpreter historic landscapes. Journal of Cultural Heritage 10(1):65-71.
- Custer J, Eveleigh T, Klemas V, Wells I. 1986. Application of Landsat data and synoptic remote sensing to predictive models for prehistoric archaeological sites: an example from the Delaware coastal plain. American Antiquity 51:572-588.

- Devos Y, Nicosia C, Vrydaghsa L, Modrieb S. 2013. Studying urban stratigraphy: Dark Earth and a microstratified sequence on the site of the Court of Hoogstraeten (Brussels, Belgium). Integrating archaeopedology and phytolith analysis. Quaternary International 315(27):147-166. http://dx.doi.org/10.1016/j. quaint.2013.07.024

- EEA. 2006: Urban sprawl in Europe. The ignored challenge. EEA Report 10/2006. Copenhagen: European Environment Agency. 60 p.

- El-Bayomi G, Ali RR. 2015. Assessment of Urban Sprawl on El Minya Archeological Sites, Egypt. Journal of Applied Sciences 15:264-270.

- European Commission. 2012. Commission Staff Working Document. Guidelines on best practice to limit, mitigate or compensate soil sealing. Brussels, 12.4.2012, SWD 2012, 101 final. http://ec.europa.eu/environment soil/pdf/soil_sealing_guidelines_en.pdf.

- Fernández Galiano D, Garcés Toledano A. 1978. Problemática y estado actual de los yacimientos arqueológicos en el Corredor Madrid-Guadalajara. Wadal Ayara 5. Revista de estudios de la Institución Provincial de Cultura Marqués de Santillana de Guadalajara. Guadalajara: UCLM. p. 7-34.

- García MP, Pérez ME. 2007. Changes in soil sealing in Guadalajara (Spain): Cartography with Landsat images. Science of the Total Environment 378(1-2):209-213

- García MP, Pérez ME. 2014. Análisis multitemporal del urbanismo expansivo en el Corredor del Henares. Aportación de las imágenes de satélite. Estudios Geográficos LXXV 27:597-618.

- García MP, Pérez ME. 2016. Mapping of soil sealing by vegetation indexes and built-up index: A case study in Madrid (Spain). Geoderma 268:100-107. http//dx.doi. org/10.1016/j.geoderma.2016.01.012.

- García MP, Pérez ME, Guerra A. 2014. Using TM images to detect soil sealing change in Madrid (Spain). Geoderma 214(15):135-140. http: //dx.doi.org/10.1016/j. geoderma.2013.09.017.

- García-Alvarado JM, Pérez ME, García MP. 2014. Revisión del concepto de sellado de suelos y propuesta de tipología urbana. Anales de Geografía de la Universidad Complutense 34:187-103.

- Giardino MJ. 2011. A history of NASA remote sensing contribution to archaeology. Journal of Archaeological Science 38:2003-2009.

- Gregory D, Matthiesen H. 2013. The 4th International Conference on Preserving Archaeological Remains In Situ (PARIS4): 23-26 May 2011, the National Museum of Denmark, Copenhagen. Editorial. Conservation and MGMT of Arch Sites 14:1-6. http://dx.doi.org/10.1179/13 50503312Z.00000000042: 1-6. 
- Hall R. 1989. Viking-Age York - an introductory survey. Actes des congrès de la Société d'archéologie médiévale $2,1: 85-93$

- Instituto Nacional de Estadística (I.N.E.). www.ine.es.

- IUSS Working Group WRB. 2007. World Reference Base for Soil Resources 2006, first update 2007. World Soil Resources reports No. 103. Rome: FAO.

- Jones RJA, Hiederer R, Rusco E, Loveland PJ, Montanarella L. 2004. The map of organic carbon in topsoils in Europe, Version 1.2, September 2003: Explanation of Special Publication Ispra 2004 No.72 (S.P.I.04.72). European Soil Bureau Research Report No.17, EUR 21209 EN and 1 map in ISO B1 format. Luxemburgo: Oficina de Publicaciones Oficiales de la Unión Europea. 26 p

- Kampouraki M, Wood GA, Brewer T. 2006. The application of Remote Sensing to identify and measure sealed areas in urban environments. In: 1st International Conference on Object-based Image Analysis (OBIA 2006).

- Kars H, van Heeringen R, editors. 2008. Preserving Archaeological Remains In Situ. In: Proceedings of the 3rd Conference, 7-9 December 2006. Amsterdam: Institute for Geo and Bioarchaeology. Geoarchaeological and Bioarchaeological Studies, vol. 10

- Klingebiel AA, Montgomery PH. 1961. Land capability classification. USDA Agricultural Handbook. Washington: US Government Printing Office. 210 p.

- Lasaponara R, Masini N. 2011. Satellite remote sensing in archaeology: past, present and future perspective. Journal of Archaelogical Science 38(9):1995-2002.

- Lasaponara R, Masini N, editors. 2012. Satellite Remote Sensing. A new tool for Archaeology.Serie. Remote Sensing and Digital Image Processing 16. Netherlands: Springer. $366 \mathrm{p}$.

- Lavalle C, Demicheli L, Kasanko M, Turchini M, Niederhuber M, McCormick N. 2001. Murbandy/Moland technical report. European Commission Euro-Report.

- Lechuga M, Martínez A. 2009. El Proyecto «Parque Arqueológico del Molinete» en el contexto del consorcio Cartagena Puerto de Culturas. In: Noguera Celdrán JM, Madrid Balanza MJ, editors. Arx Hasdrubalis. La ciudad reencontrada. Arqueología en el cerro del Molinete, Cartagena. Murcia: Ayuntamiento de Cartagena. p. 3846.

- Milek KB, Roberts HM. 2013. Integrated geoarchaeological methods for the determination of site activity areas: a study of a Viking Age house in Reykjavik, Iceland. Journal of Archaeological Science 40(4):18451865. http://dx.doi.org/10.1016/j.jas.2012.10.031

- Moeller M. 2005. Remote Sensing for the monitoring of urban growth patterns. Proceddings of the ISPRS Joint Conference URBAN/URS. Tempe, AZ, USA.
- Montanarella L. 2007. Trends in land degradation in Europe. In: Sivakumar MVK, Ndegwa N, editors. Climate and Land Degradation. Germany: Springer-Heidelberg. p. 83-104.

- Monturiol F, Alcalá L. 1990a. Mapa de asociaciones de suelos de la Comunidad de Madrid. Escala 1:200.000. $1^{\text {a }}$ edición. Madrid: C.S.I.C., Comunidad de Madrid. 71 p.

- Monturiol F, Alcalá L. 1990b. Mapa de Capacidad Potencial de Uso Agrícola de la Comunidad de Madrid. Escala 1:200.000. $1^{a}$ edición. Madrid: C.S.I.C., Comunidad de Madrid. $31 \mathrm{p}$.

- Netzband M, Meinel G. 1998. Identifying Urban Soil Sealing by High Resolution Remote Sensing Methods. In: Breuste J, Feldmann H, Uhlmann O, editors. Urban Ecology. Springer-Verlag Berlin Heidelberg. p. 451-455.

- Nixon T, editor. 2004. Preserving archaeological remains in situ? Proceedings of the 2nd Conference 12-14 September 2001. London: Museum of London Archaeology Service (MOLAS).

- Nodar R, Mateos P. 2010. La adecuación museográfica del yacimiento emeritense. In: Álvarez Martínez JM, Mateos Cruz P, editors. Mérida. 2000 años de Historia, 100 años de Arqueología. Madrid: Consorcio de la Ciudad Monumental de Mérida. p. 195-213.

- Palma F. 2010. Las competencias autonómicas: una nueva etapa en la arqueología emeritense (1984-2010). In: Álvarez Martínez JM, Mateos Cruz P, editors. Mérida. 2000 años de Historia, 100 años de Arqueología. Madrid: Consorcio de la Ciudad Monumental de Mérida. p. 175193.

- Parcak S. 2007. Satellite Remote Sensing Methods for Monitoring Archaeological Tells in the Middle East. Journal of Field Archaeology Vol. 32(1):65-81.

- Parcak S. 2009. Satellite Remote Sensing for Archaeology. New York: Routledge Press.

- Pérez ME, García MP. 2013. Aplicaciones de la Teledetección en degradación de suelos. Boletín de la Asociación de Geógrafos Españoles 61:285-308.

- Raymaekers D, Bauwens I, Van Orshoven J, Gulinck $\mathrm{H}$, Engel B, Dosselaere N. 2005. Spectral unmixing of low resolution images for monitoring Soil Sealing. 3rd International Symposium Remote Sensing and Data Fusion Over Urban Areas (URBAN 2005).

- Sánchez Montes AL, Rascón Marqués S. 2011. Complutum, ciudad romana. Madrid: Ayuntamiento de Alcalá de Henares.

- Scalenghe R, Ajmone-Marsan F. 2009. The anthropogenic sealing of soils in urban areas. Landscape and Urban Planning 90:1-10.

- Shoup DC. 2006. Archaeology Build a Dam? Sites and Politics in Turkey's Southeast Anatolia Project. Journal of Mediterranean Archaeology 19(2):231-258. 
- Smith M. 2010. Sprawl, Squatters and Sustainable Cities Can Archaeological Data Shed Light on Modern Urban Issues? Cambridge Archaeological Journal 20(2):229-53.

- Tomás A, Salas FJ, Santos C, Garzón A, Moreno V. 2010. Estimación del sellado del suelo mediante técnicas de análisis espectral. Serie Geográfica 16:81-92.

- UNESCO. 1969. La protección del patrimonio cultural de la humanidad. París: Organización de las Naciones Unidas para la Educación, la Ciencia y la Cultura. 79 p.

- Wiseman J, El-Baz F. 2007. Remote Sensing in Archaeology. New York: Springer Press.

- Zhang Q, Wang J, Gongc P, Shib P. 2003. Study of urban spatial patterns from SPOT panchromatic imagery using textural analysis. International Journal of Remote Sensing 24(21): 4137-4160. 